\title{
Antibacterial and antibiofilm properties of yttrium fluoride nanoparticles
}

\author{
This article was published in the following Dove Press journal: \\ International Journal of Nanomedicine \\ 2 November 2012 \\ Number of times this article has been viewed
}

\section{Jonathan Lellouche ${ }^{1,2}$ Alexandra Friedman ${ }^{2}$ \\ Aharon Gedanken ${ }^{2}$ Ehud Banin'}

'Biofilm Research Laboratory, The Mina and Everard Goodman Faculty of Life Sciences, ${ }^{2}$ Kanbar Laboratory for Nanomaterials, Department of Chemistry, Institute for Nanotechnology and Advanced Materials, Bar-Ilan University, Ramat-Gan, Israel
Correspondence: Ehud Banin Biofilm Research Laboratory, The Mina and Everard Goodman Faculty of Life Sciences, Institute for Nanotechnology and Advanced Materials, Bar-llan University, Ramat-Gan, 52900, Israel Tel +97235317288

Fax+97235384058

Email ehud.banin@biu.ac.il
Abstract: Antibiotic resistance has prompted the search for new agents that can inhibit bacterial growth. Moreover, colonization of abiotic surfaces by microorganisms and the formation of biofilms is a major cause of infections associated with medical implants, resulting in prolonged hospitalization periods and patient mortality. In this study we describe a water-based synthesis of yttrium fluoride ( $\left.\mathrm{YF}_{3}\right)$ nanoparticles (NPs) using sonochemistry. The sonochemical irradiation of an aqueous solution of yttrium (III) acetate tetrahydrate $\left[\mathrm{Y}(\mathrm{Ac})_{3} \cdot\left(\mathrm{H}_{2} \mathrm{O}\right)_{4}\right]$, containing acidic $\mathrm{HF}$ as the fluorine ion source, yielded nanocrystalline needle-shaped $\mathrm{YF}_{3}$ particles. The obtained NPs were characterized by scanning electron microscopy and X-ray elemental analysis. NP crystallinity was confirmed by electron and powder X-ray diffractions. $\mathrm{YF}_{3} \mathrm{NPs}_{\mathrm{s}}$ showed antibacterial properties against two common bacterial pathogens (Escherichia coli and Staphylococcus aureus) at a $\mu \mathrm{g} / \mathrm{mL}$ range. We were also able to demonstrate that antimicrobial activity was dependent on NP size. In addition, catheters were surface modified with $\mathrm{YF}_{3}$ NPs using a one-step synthesis and coating process. The coating procedure yielded a homogeneous $\mathrm{YF}_{3} \mathrm{NP}$ layer on the catheter, as analyzed by scanning electron microscopy and energy dispersive spectroscopy. These $\mathrm{YF}_{3} \mathrm{NP}$-modified catheters were investigated for their ability to restrict bacterial biofilm formation. The $\mathrm{YF}_{3} \mathrm{NP}$-coated catheters were able to significantly reduce bacterial colonization compared to the uncoated surface. Taken together, our results highlight the potential to further develop the concept of utilizing these metal fluoride NPs as novel antimicrobial and antibiofilm agents, taking advantage of their low solubility and providing extended protection.

Keywords: yttrium fluoride, nanoparticles, biofilms, antibacterial, catheter, sterile surfaces

The application of nano-scale materials and structures is an emerging area of material science and nanotechnology. Continuing advances in nanotechnology promise to be of great benefit for a wide variety of applications including various medicinal uses, such as therapeutics, diagnostic, or drug delivery. ${ }^{1-5}$ The increased resistance of bacteria to traditional antibiotics has created a great need for the development of new antimicrobial agents. ${ }^{6,7}$ The application of nanomaterials as new antimicrobials can provide novel modes of action and/or different cellular targets in comparison with existing antibiotics. ${ }^{8,9}$ Nanomaterials often show unique and considerably changed physical, chemical, and biological properties compared to their macro-scale counterparts, and therefore it is desirable to develop methods for fabricating these nanostructures with properties that are tunable for specific applications. For example, ceramic powders of nano-sized metal oxides, such as $\mathrm{ZnO},{ }^{10} \mathrm{MgO},{ }^{11,12}$ and $\mathrm{CuO},{ }^{13,14}$ have been found to exhibit high antibacterial activity. Several studies have established that metal oxides 
can produce some species of oxyradicals that are generated on the oxide surface. ${ }^{15-17}$

Biofilms are bacterial communities encased in a selfproduced hydrated polymeric matrix. An important characteristic of microbial biofilms is their innate resistance to immune systems and eradication due to antibiotics, ${ }^{18-21}$ making microbial biofilms a common and difficult-to-treat cause of medical infections. A major contribution to this statistic arises from the fact that biofilms are a major cause of infections associated with medical implants. The current situation raises an urgent need to design surfaces that can restrict bacterial colonization and biofilm formation. Several studies have shown the "nano-functionalization" of surfaces to inhibit bacterial adhesion and biofilm formation. Examples include the functionalization of biomaterials with antibacterial properties by coating, ${ }^{22,23}$ impregnation, ${ }^{24,25}$ or embedding nanomaterials. ${ }^{26}$

Fluorides are well known for their antibacterial activity and act in multiple ways to affect the metabolism of bacteria. ${ }^{27}$ $\mathrm{F}^{-} / \mathrm{HF}$ can bind directly to many enzymes, for example, hemecontaining enzymes or other metalloenzymes, to modulate metabolism. ${ }^{27,28}$ Fluoride is also able to form complexes with metals such as aluminum or beryllium, and the complexes, notably $\mathrm{AlF}_{4}^{-}$and $\mathrm{BeF}_{3}{ }^{-} \cdot \mathrm{H}_{2} \mathrm{O}$, can mimic phosphate, with either positive or negative effects on a variety of enzymes and regulatory phosphatases. ${ }^{27,28}$ The fluoride action that appears to be the most important for glycolytic inhibition derives from its weak acid properties and the capacity of $\mathrm{HF}$ to act as a transmembrane proton conductor. ${ }^{28}$ Our group has recently demonstrated the antibacterial and antibiofilm properties of highly crystalline, $25 \mathrm{~nm}$-sized magnesium fluoride $\left(\mathrm{MgF}_{2}\right)$ nanoparticles (NPs) using different chemistries for their synthesis. ${ }^{29,30}$ Antimicrobial activity of $\mathrm{MgF}_{2}$ NPs was highly dependent on the size of the NP. ${ }^{30}$ Our results revealed that NPs penetrate the cells, reduce the internal $\mathrm{pH}$, cause disruption to the membrane potential, and enhance lipid peroxidation. ${ }^{29,30}$ We utilized this new metal fluoride nanomaterial to coat glass slide coupons and showed that the coated surfaces can restrict bacterial colonization and biofilm formation for up to 7 days. ${ }^{30} \mathrm{We}$ also described the method for depositing $\mathrm{MgF}_{2} \mathrm{NPs}$ on latex-based catheters in a one-step process and for obtaining a long-lasting $\mathrm{MgF}_{2}$ NP coating, even following exposure to various biological fluids, such as artificial urine and plasma. ${ }^{33}$

The objective of this study was to present a new nanosized metal fluoride with a lower solubility compared to $\mathrm{MgF}_{2} \mathrm{NPs}$. We hypothesized that reduction in solubility may result in improved or extended NP antimicrobial and antibiofilm efficacy. We utilized a simple and fast sonochemical-based synthesis to obtain yttrium fluoride $\left(\mathrm{YF}_{3}\right)$ NPs and characterized their antibacterial activity against two common nosocomial pathogens, Escherichia coli and Staphylococcus aureus. We also examined the antibiofilm properties of these NPs and the ability of NP-coated catheters to inhibit bacterial colonization and biofilm development. The results presented suggest that the nanometric $\mathrm{YF}_{3}$ with a less soluble fluoride is responsible for the antimicrobial activity and the antibiofilm properties of NP-coated surfaces. We also provide preliminary results of a comparison between $\mathrm{YF}_{3}$ and $\mathrm{MgF}_{2} \mathrm{NPs}$ and the influence of the solubility to the internalization of fluorine into the cells. These findings provide a new approach for the future development of self-sterilizing surface coatings based on metal fluoride NPs.

\section{Materials and methods $\mathrm{YF}_{3} \mathrm{NP}$ synthesis}

Yttrium (III) acetate tetrahydrate $\left(\left[\mathrm{Y}(\mathrm{Ac})_{3} \cdot\left(\mathrm{H}_{2} \mathrm{O}\right)_{4}\right]\right)$, 99\% purity; Sigma-Aldrich, St Louis, MO) and concentrated hydrofluoric acid (HF, 32\% weight aqueous solution, American Chemical Society grade; BioLab, Auckland, New Zealand) were dissolved in double-distilled water (DDW, $100 \mathrm{~mL}$ ) at a 1:2 equivalent ratio for all the prepared $\mathrm{YF}_{3} \mathrm{NPs}_{\text {. }}$ More specifically, three $\mathrm{YF}_{3} \mathrm{NP}$ samples, varying in size of NPs, were prepared by decreasing HF concentration as follows: $0.02 \mathrm{M} \mathrm{HF}\left(\mathrm{YF}_{3}-1\right), 0.002 \mathrm{M} \mathrm{HF}\left(\mathrm{YF}_{3}-2\right)$, and 0.0002 $\mathrm{M} \mathrm{HF}\left(\mathrm{YF}_{3}-3\right)$. The $\mathrm{Y}: \mathrm{F}$ molar ratio was maintained as 1:3 for all three samples. During the NP fabrication, each separate mixture was irradiated with a high-intensity ultrasonic horn (Ti-horn [Sonics and Materials, Newton, CT], $20 \mathrm{kHz}$, $750 \mathrm{~W} \times \mathrm{cm}^{-2}, 60 \%$ power modulation) under argon (60 minutes, room temperature). In all reactions, the temperature was maintained constant at $25^{\circ} \mathrm{C}$ by placing the reaction vessel in a water bath during sonochemical irradiation. The resulting precipitating products were washed thoroughly with $\mathrm{DDH}_{2} \mathrm{O}$ $(3 \times 10 \mathrm{~mL})$, absolute EtOH $(2 \times 10 \mathrm{~mL})$, and dried in a vacuum $\left(10^{-2} \mathrm{mmHg}\right)$ in an inert glove box $\left(\mathrm{O}_{2}<1 \mathrm{ppm}\right)$.

\section{$\mathrm{YF}_{3} \mathrm{NP}$ characterization}

NP morphology was imaged by scanning electron microscopy (SEM, FEI, Inspect ${ }^{\mathrm{TM}} \mathrm{S}$, Hillsboro, OR), and the X-ray elemental spectra were collected by an EDAX (Mahwah, NJ) apparatus on the FEI-Inspect S. The length and width of the particles and the size distributions were determined from the measurement of the images obtained by the SEM measurements. The sizes were averaged over 100 NPs using the SCION Image software V2.0 (Scion Software Solutions, Hyderabad, India). $\mathrm{X}$-ray diffraction (XRD) measurements were carried out on a Bruker D8 diffractometer (Bruker Analytical X-Ray Systems, 
Madison, WI), using $\mathrm{Cu} K \alpha$ radiation $(\lambda=1.5418 \AA$ ). Peak fitting and lattice parameter refinement were computed using the EVA program (Bruker Analytical X-Ray Systems). Size of NPs was calculated also from the XRD pattern by employing the Debye-Scherrer equation. ${ }^{10}$ The sizes and size distribution in the solution were determined by measuring the dynamic light scattering (Beckman Coulter N-4 particle size analyzer; Beckman Coulter, Nyon, Switzerland). The NP surface area was measured using a Micrometrics analyzer (Gemini 2375; Micrometrics, Norcross, GA) in the linear part of the Brunauer-Emmett-Teller (BET) plot of the $\mathrm{N}_{2}$ adsorption/ desorption isotherms of each separate $\mathrm{YF}_{3}$ sample; all measurements were performed in triplicate. The crystallinity of the NPs was characterized using a high-resolution transmission electron microscopy (HR-TEM; JEOL-2010 HR-TEM apparatus, accelerating voltage $200 \mathrm{kV}$; JEOL Ltd, Tokyo, Japan). NP samples for HR-TEM analysis were prepared in absolute EtOH (ultrasonic dispersion), deposited onto a copper-coated grid (drop deposition), and then dried under vacuum $\left(10^{-2} \mathrm{mmHg}\right)$ before sample processing.

\section{Bacterial cultures and growth conditions}

Escherichia coli 1313 (clinical isolate) and Staphylococcus aureus 8325 (clinical isolate) were grown at $37^{\circ} \mathrm{C}$ in tryptic soy broth (TSB; Difco ${ }^{\mathrm{TM}}$, BD, Franklin Lakes, NJ) and tryptic soy broth $66 \%$, supplemented with glucose $0.2 \%$ (TSB-Glu; Difco) media, respectively. These media were chosen based on their ability to promote robust $E$. coli and $S$. aureus biofilm formation. ${ }^{34,35}$

\section{Statistical analysis}

Data analyses were performed using a GraphPad Prism software program (V5.0, GraphPad Software Inc, San Diego, CA). The collected data were statistically analyzed by oneway analysis of variance to evaluate the differences. The threshold for the statistical significance was set at $P<0.05$.

\section{Antibacterial assay}

Antimicrobial activity of the $\mathrm{YF}_{3}$ NPs was examined on logarithmic phase cultures by using a modified macrodilution assay. Briefly, overnight cultures of tested bacteria were diluted (1:100) in fresh TSB or TSB-Glu and grown for 4 hours at $37^{\circ} \mathrm{C}$ (shaking, $250 \mathrm{rpm}$ ) to allow the cells to reenter logarithmic phase. Following this the bacteria were diluted again to $10^{3}$ colony forming units per $\mathrm{mL}(\mathrm{CFU} / \mathrm{mL})$ in the appropriate growth media. One hundred microliters of the tested cell suspension was then added to each well of a 96-well plate, and $\mathrm{YF}_{3} \mathrm{NP}$ samples at various concentrations $(0.0001$ to $1.0 \mathrm{mg}$ of $\mathrm{YF}_{3} / \mathrm{mL}$ ) were also added. Cell growth was monitored by measuring the absorbance for 24 hours at an optical density at $595 \mathrm{~nm}\left(\mathrm{OD}_{595}\right)$ by using a microplate reader $\left(\right.$ Synergy ${ }^{\mathrm{TM}}$ 2, BioTek Instruments Inc, Winooski, VT) at $37^{\circ} \mathrm{C}$.

\section{Determination of the extracellular and intracellular concentrations of fluorine}

Bacterial cultures of $E$. coli and $S$. aureus containing approximately $1.0 \times 10^{5} \mathrm{CFU} / \mathrm{mL}$ (see bacterial cultures and growth conditions section) were exposed to $\mathrm{MgF}_{2}$ and $\mathrm{YF}_{3}$ NPs at a concentration of $0.01 \mathrm{mg} / \mathrm{mL}$. Because of the very low fluorine concentrations, the ionic strength of examined solutions was fixed with a total ionic strength adjustment buffer (TISAB; $5.84 \mathrm{~g} \mathrm{NaCl}, 5.75 \mathrm{~mL}$ glacial acetic acid, and 0.45 g trans-1,2-diamino-cyclohexane-N,N,N,N-tetraacetic acid monohydrate for a final volume of $100 \mathrm{~mL}$; all reagents used as received from Sigma-Aldrich, St Louis, MO) before measurements. After 2 hours of incubation, the extracellular medium was removed from bacterial cells by centrifugation (16,000 relative centrifugal force [rcf], 5 minutes, $\left.20^{\circ} \mathrm{C}\right)$. Aliquots $(1 \mathrm{~mL})$ of the extracellular medium were added to the TISAB (4 mL) solutions, and fluorine $\left(\left[\mathrm{F}^{-}\right]_{\mathrm{ex}}\right)$ was measured using an ion-sensitive electrode ( $\mathrm{F}^{-}$-ISE) on a $781 \mathrm{pH} /$ ion meter (Methrom AG, Herisau, Switzerland). The intracellular concentration of fluorine $\left(\left[\mathrm{F}^{-}\right]_{\text {in }}\right)$ was determined after cell lysis (of the cells obtained after centrifugation, see above) using $10 \%$ ice-cold trichloroacetic acid (Sigma-Aldrich). The lysis mixture was centrifuged for 5 minutes at 16,000 rcf (Centrifuge 5418; Eppendorf, Harburg, Germany). Aliquots (1 mL) of the obtained supernatant were added to the TISAB $(4 \mathrm{~mL})$ solutions, and fluorine concentrations measured by $\mathrm{F}^{-}$-ISE. Untreated bacteria served as control.

\section{Static biofilm formation assay}

Overnight cultures of tested bacteria were diluted 1:100 in fresh media and grown for 4 hours at $37^{\circ} \mathrm{C}$ with shaking (250 rpm). Water-insoluble compounds were assayed in a modified macrodilution broth format. Compounds ( 0.0001 to $1 \mathrm{mg} / \mathrm{mL}$ ) were placed in sterile polypropylene tubes (Greiner Bio-One, Frickenhausen, Germany) to which the appropriate volume of a solution containing approximately $1.0 \times 10^{7}$ $\mathrm{CFU} / \mathrm{mL}$ of $E$. coli or $S$. aureus in media was added. One hundred microliters of the tested cell suspension was added to each well in a 96-well plate and was incubated for 24 hours at $37^{\circ} \mathrm{C}$. Following incubation the wells were washed twice with DDW to remove nonattached cells and stained with $1 \%$ crystal violet (Sigma-Aldrich, St Louis, MO) for 15 minutes at room temperature. Stained wells were than washed five times with DDW, and the remaining crystal violet was eluted by the addition of absolute ethanol for 15 minutes. The biofilm 
biomass was then determined by measuring the absorbance at $\mathrm{OD}_{595}$.

\section{Catheter-coating procedure and characterization}

Five-centimeter-length segments of latex-based Foley catheter (Unomedical, Birkerod, Denmark) were coated by placing the catheter segments directly into the sonochemical reaction medium according to the methodology described in YF3 NP synthesis. This one-step sonication in which the NPs are synthesized and subsequently "thrown" at the solid surface present in the sonication cell has been previously described. . $2,33^{2}$

After completion of sonication, the sonochemically coated catheters were washed with DDW $(3 \times 10 \mathrm{~mL})$ followed by absolute EtOH $(2 \times 10 \mathrm{~mL})$ and allowed to dry in a vacuum $\left(10^{-2} \mathrm{mmHg}\right)$. Next, the samples were coated with chromium and imaged by SEM (FEI-Inspect S, accelerating voltage $15 \mathrm{kV}$ ).

The amount of $\mathrm{YF}_{3}$ NPs on the catheter surfaces was determined by soaking the catheter in $5 \mathrm{M} \mathrm{HNO}_{3}$; the yttrium concentration was then determined by inductively coupled plasma (ULTIMA 2; Horiba Ltd, Kyoto, Japan). Uncoated catheter segments served as a negative control. To evaluate the distribution of coating on the surface, we mapped the yttrium and fluorine elemental distributions on the wall by energy-dispersive spectroscopy (EDAX apparatus on the FEI-Inspect S). Elemental mapping was performed for both coated and uncoated samples at $15 \mathrm{keV}$ and $0.58 \mathrm{nA}$ with a resolution of $133 \mathrm{eV}$. Maps were created in most cases from 100 scan frames by using a dwell time of $100 \mu$ s and a pixel/ frame resolution of $512 \times 384$. To exclude undesirable NP leaching from catheter walls, the segments were previously washed for 24 hours in sterile TSB or TSB-Glu before antibiofilm experiments.

\section{Antibiofilm assays on NP-coated catheters}

We evaluated the antibiofilm properties of the coating using a continuous culture flow model..$^{29,30}$ A $5 \mathrm{~cm}$ catheter segment was inoculated with $\mathrm{OD}_{595}=0.3$ (approximately $1.5 \mathrm{~mL}$ at a concentration of $3 \times 10^{8} \mathrm{CFU} / \mathrm{mL}$ ) of an E. coli or $S$. aureus culture. The flow was initiated after 1 hour with a flow rate of $10 \mathrm{~mL} /$ hour. The system was incubated at $37^{\circ} \mathrm{C}$ for 24 hours. Following incubation the catheters were washed to remove free-living bacteria and then biofilm cells were extracted mechanically. The cells were diluted in 1\% Luria-Bertani (Difco) and plated for viable counting. The reduction in colonization was determined by calculating the $\mathrm{CFU} / \mathrm{mL}$ of the culture. An uncoated catheter served as negative control.

\section{Results and discussion $\mathrm{YF}_{3}$ NP synthesis and characterization}

To obtain $\mathrm{YF}_{3}$ NPs, we optimized a protocol previously described for the synthesis of $\mathrm{MgF}_{2} \mathrm{NPs}^{30}$ In brief, we utilized a sonication process containing an aqueous solution of $\left[\mathrm{Y}(\mathrm{Ac})_{3} \cdot\left(\mathrm{H}_{2} \mathrm{O}\right)_{4}\right]$ and acidic HF (Figure 1). The optimized set of reaction parameters ( 1 hour reaction time, $0.02 \mathrm{M} \mathrm{HF}$, and $60 \%$ power modulation) afforded needle-shaped $\mathrm{YF}_{3}$ nanostructure morphology (Figures $2 \mathrm{~A}$ and $3 \mathrm{~B}$ ) with a length of $342( \pm 51) \mathrm{nm}$ and a width of $52( \pm 12) \mathrm{nm}$ (Figure 2C and D). NPs were also characterized by elemental analysis and revealed atomic percentages of $\sim 25 \mathrm{At} \%$ and $\sim 75 \mathrm{At} \%$ for fluorine and yttrium, respectively (Figure $2 \mathrm{~B}$ ). These results confirmed the 1:3 atomic ratios between fluorine and yttrium atoms in $\mathrm{YF}_{3}$ NPs.

The powder XRD analysis of the NPs showed a clear crystalline pattern (Figure 3A). The XRD pattern matched well with the reflection peaks of the orthorhombic $\mathrm{YF}_{3}$ phase (Joint Committee on Powder Diffraction Standards [JCPDS] card No 01-070-1935), ${ }^{31}$ characterized by diffraction planes (101), (020), (111), (210), (121), (002), (221), (131), (301), (230), (112), (212), and (400) (Figure 3A). No additional diffraction peaks of any impurity were detected, demonstrating the high purity of the product. In addition, the average size of crystallites calculated by the DebyeScherrer equation afforded a value of $358 \mathrm{~nm}$, which is similar to the average length size measured by SEM (ie, $342( \pm 51) \mathrm{nm}$, Figure 2C). Characteristic lattice fringes of the crystalline phase were also revealed (Figure $3 \mathrm{C}$ ). The measured interfringe distance of $3.6 \AA$ and $3.1 \AA$ perfectly matches the (101) and (111) interplanar distances (JCPDS card No 01-070-1935). ${ }^{32}$ The diffraction planes were also confirmed by selected area electron diffraction; a polycrystalline pattern was observed, and a complete agreement with the XRD-diffraction planes could be calculated (Figure 3D).

\section{$\mathrm{YF}_{3}$ NPs antibacterial and antibiofilm properties}

To begin to characterize the antimicrobial activity of $\mathrm{YF}_{3}$ NPs, we first examined the growth of two common bacterial pathogens, E. coli and $S$. aureus, in the presence of different concentrations of suspended $\mathrm{YF}_{3}$ NPs. The results, as presented in Figure 4A and B, demonstrated that for both bacteria, $\mathrm{YF}_{3}$ NPs caused a reduction in growth in a dose- 


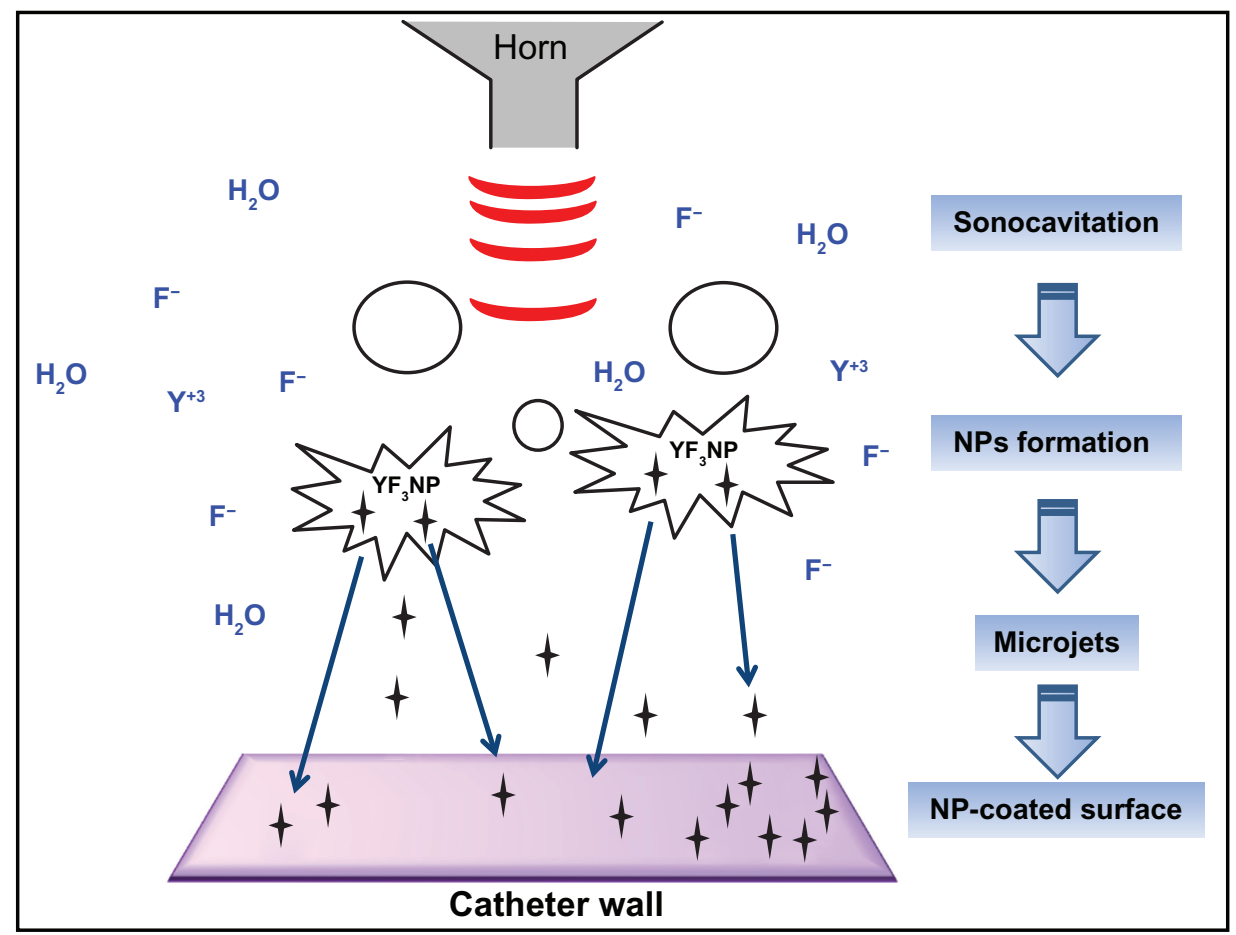

Figure I General view of the synthesis of $\mathrm{YF}_{3}$ NPs and NP deposition on a surface by sonochemistry.

Notes: $\mathrm{YF}_{3}$ (black stars) is formed under ultrasonic irradiation (red waves). Microjets (blue arrows) are formed after the collapse of the acoustic bubble near the catheter wall and eject the NPs to create a $\mathrm{YF}_{3} \mathrm{NP}$ coating.

Abbreviations: $\mathrm{NP}$, nanoparticle; $\mathrm{YF}_{3}$, yttrium fluoride.

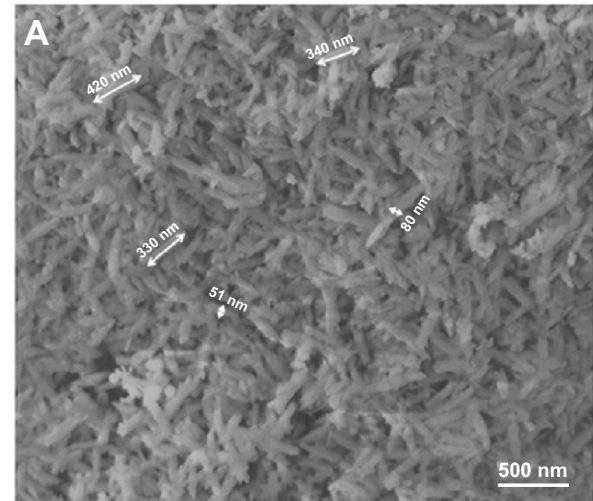

B

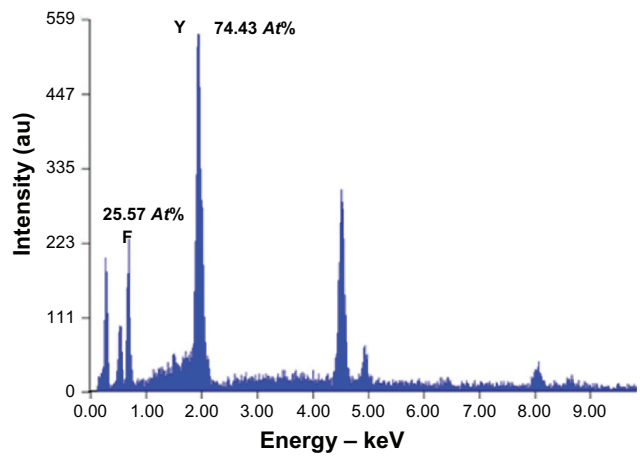

C

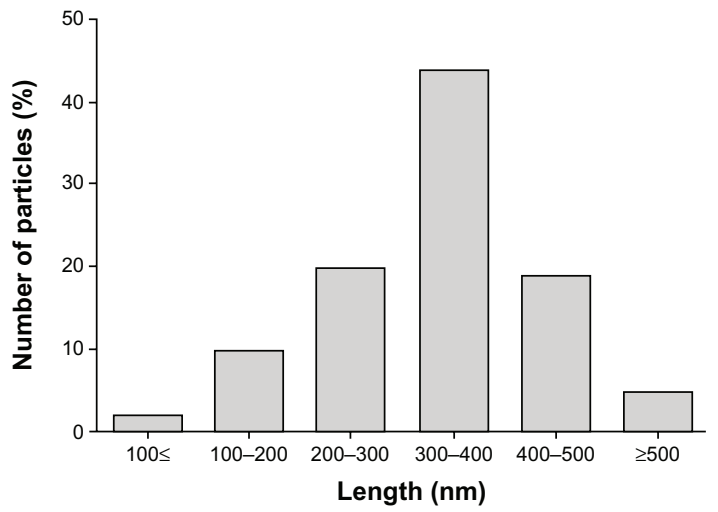

D

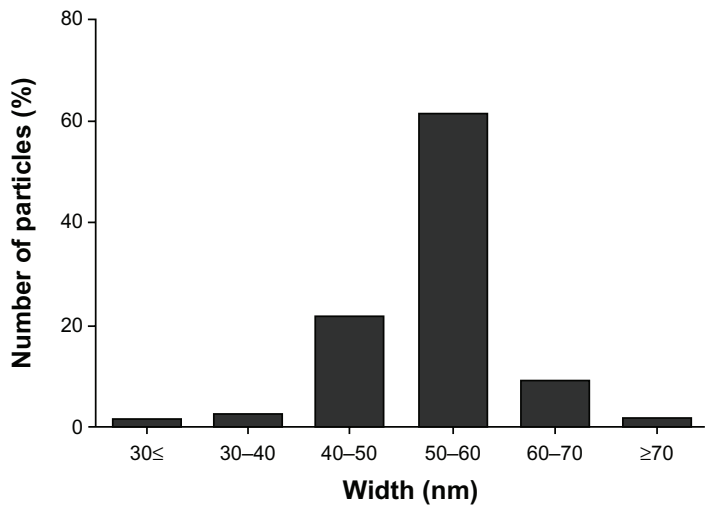

Figure $2 \mathrm{YF}_{3} \mathrm{NP}$ characterization. (A) SEM micrograph and $(\mathbf{B}) \mathrm{X}$-ray elemental spectra of $\mathrm{YF}_{3} \mathrm{NPs}$. Percentages indicated in (B) refer to the relative atomic ratio between fluor and yttrium atoms. (C and D) Nanoparticle length and width distributions.

Abbreviations: NP, nanoparticle; SEM, scanning electron microscope; $\mathrm{FF}_{3}$, yttrium fluoride. 
A
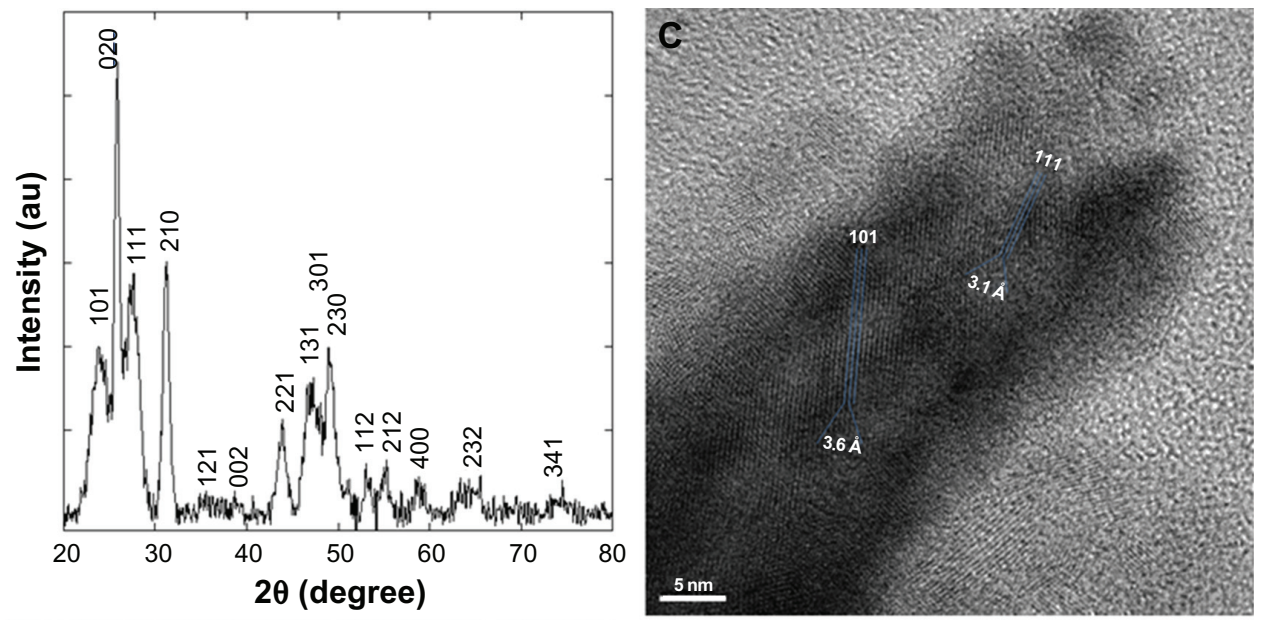

B
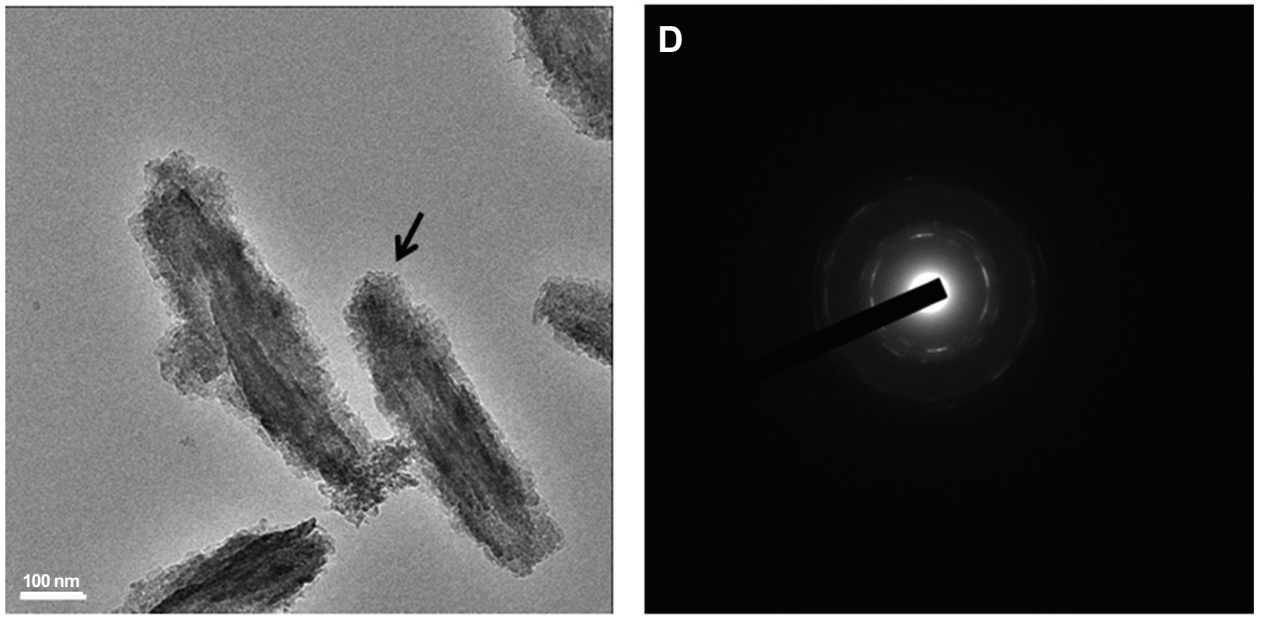

Figure $3 \mathrm{YF}_{3}$ NP crystallinity characterization. (A) Powder XRD analysis of the crystalline NPs. The XRD pattern matched the reflection peaks and relative Miller indices of orthorhombic $\mathrm{YF}_{3}$. (B) HR-TEM micrographs of $\mathrm{YF}_{3} \mathrm{NPs}_{\mathrm{S}}$ and $(\mathbf{C})$ characteristic lattice fringes of the crystalline phases indicated by the black arrow in (B). (D) Selected area diffraction patterns of polycrystalline $\mathrm{YF}_{3} \mathrm{NPs}$ shown in (B).

Abbreviations: HR-TEM, high-resolution transmission microscope; NP, nanoparticle; XRD, X-ray diffraction; $\mathrm{YF}_{3}$, yttrium fluoride.

dependent manner. The minimal inhibitory concentration (MIC) was observed for E. coli at $0.01 \mathrm{mg} / \mathrm{mL}$ of NPs (Figure 4A). Staphylococcus aureus seemed to be less sensitive, and a concentration of $0.1 \mathrm{mg} / \mathrm{mL}$ inhibited its growth completely (Figure 4B).

To understand the impact of NP dissolution on antimicrobial activity, we compared the observed activity of $\mathrm{YF}_{3}$ NPs with that of $\mathrm{MgF}_{2}$ NPs described previously ${ }^{29-30,33}$ (see Figures 4 and S2). It is well known that both salts, $\mathrm{YF}_{3}$ and $\mathrm{MgF}_{2}$, have very different $\mathrm{K}_{\mathrm{sp}}$ values $\left(8.16 \times 10^{-21}\right.$ and $5.6 \times 10^{-14}$, respectively). ${ }^{36}$ One possible mechanism that can explain the difference in antimicrobial activity observed with the two NPs is differences in fluoride anion concentrations (internal and external). To test this we exposed bacteria for 2 hours to $0.01 \mathrm{mg} / \mathrm{mL}$ of each NP. Following incubation the $\mathrm{F}^{-}$molarities of surrounding media $\left(\left[\mathrm{F}^{-}\right]_{\mathrm{ex}}\right)$ was $\left[\mathrm{F}^{-}\right]_{\mathrm{ex}}=10^{-11} \mathrm{M}$ for $\mathrm{YF}_{3}$ and $\left[\mathrm{F}^{-}\right]_{\mathrm{ex}}=10^{-7} \mathrm{M}$ for $\mathrm{MgF}_{2}$, values that are coherent with the theoretical dissolution values of both salts (Figure 5). We also measured the internal concentration $\left(\left[\mathrm{F}^{-}\right]_{\text {in }}\right)$. For $S$. aureus the internal concentration for $\mathrm{MgF}_{2}$-exposed cells was found to be $10^{3}$-fold higher ([Fin $\left.=10^{-5} \mathrm{M}\right)$ than that obtained for $\mathrm{YF}_{3}$-exposed cells $\left(\left[\mathrm{F}^{-}\right]\right.$ in $\left.=10^{-8} \mathrm{M}\right)($ Figure 5$)$. The increase in fluoride intracellular concentration correlated with the enhanced antimicrobial activity observed for $\mathrm{MgF}_{2}$ in $S$. aureus compared to $\mathrm{YF}_{3}$. Interestingly for $E$. coli the internal concentration was similar for both NP (around $10^{-9} \mathrm{M}$ ), although the MIC was different between particles (Figure 5). Thus, the difference in solubility does not seem to influence the internalization of the fluorine ion into the $E$. coli cell. Furthermore, our results suggest that antibacterial activities mediated by both particles cannot simply be related to the fluoride concentration in the case of E. coli. It is most likely that additional parameters, such as the possible interaction of the NP with the cell membrane and their impact on the membrane integrity, can be a major factor. Additional parameters may include NP shape and 

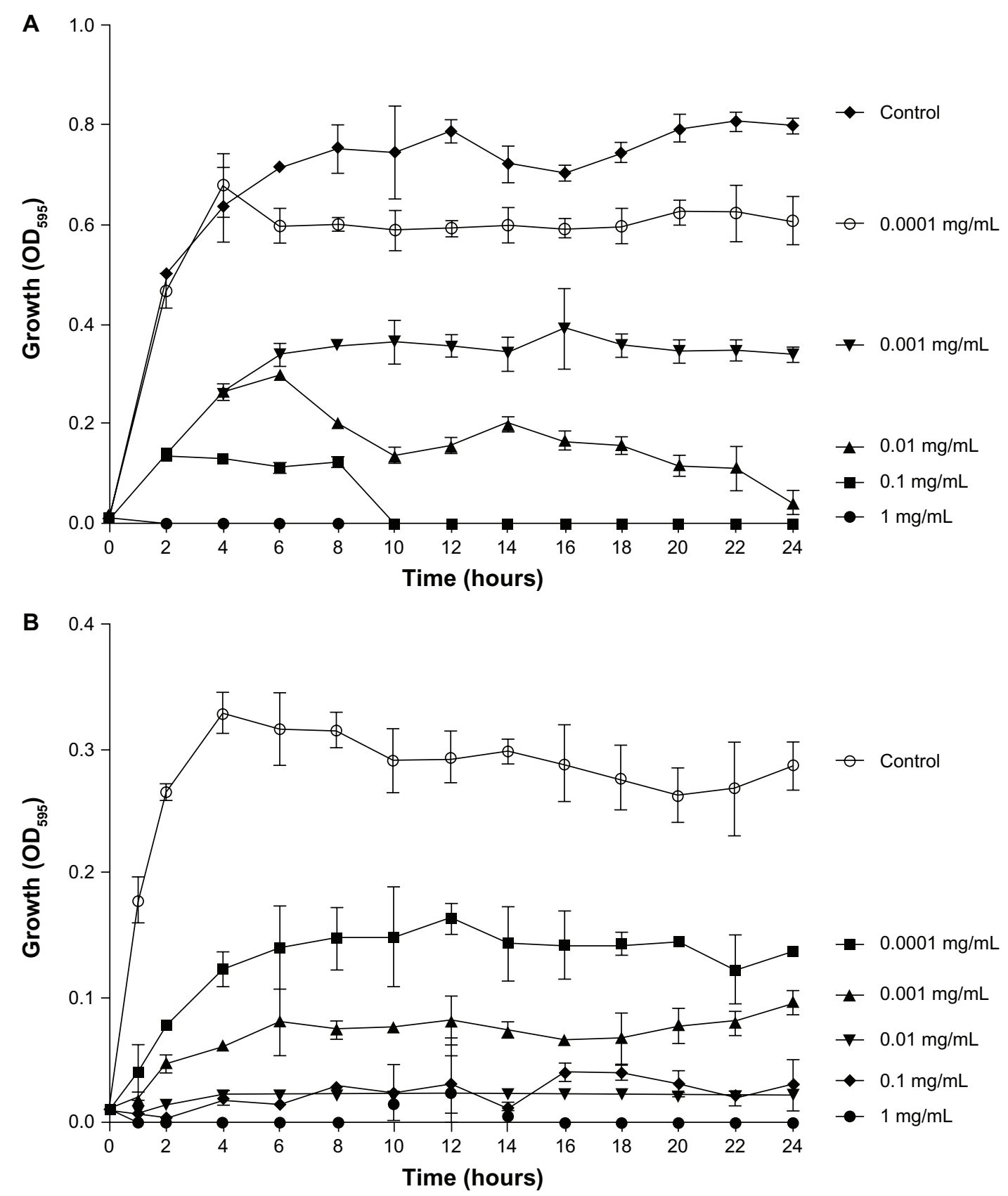

Figure 4 Antimicrobial effect of $\mathrm{YF}_{3} \mathrm{NPs}$. Growth curves of $(\mathbf{A})$ Escherichia coli and $(\mathbf{B})$ Staphylococcus aureus exposed to variable concentrations $(0.000 \mathrm{I}$ to I mg/mL) of $\mathrm{YF}$ NP solutions for 24 hours at $37^{\circ} \mathrm{C}$.

Notes: Untreated bacteria served as a control. Error bars represent the standard deviation of three independent experiments conducted in triplicate. The results were found to be statistically significant $(P<0.05)$ between control versus NP-treated cells in all treatments.

Abbreviations: NP, nanoparticle; $\mathrm{OD}_{595}$, optical density at $595 \mathrm{~nm} ; \mathrm{YF}_{3}$, yttrium fluoride.

crystallinity. These physicochemical properties can play a critical role in the antibacterial mechanism of nano-sized materials. This was previously described for other materials, such as metal oxide NPs. For example, the ability of titania and $\mathrm{ZnO}$ to release reactive oxygen species directly depends on their crystalline lattice and shape. ${ }^{16,36}$ Another parameter to consider is the difference in the physiological response. A recent study conducted by Baker et $\mathrm{al}^{37}$ indicated that
E. coli exposed to toxic levels of fluorine use fluorine-sensing RNAs to control the expression of proteins that alleviate the deleterious effects of this anion. These fluorine-specific riboswitches and commonly associated proteins, such as camphor resistance $\mathrm{CrcB}$ protein, may represent an efficient system by which cells have dealt with toxic levels of this anion. ${ }^{37}$ It is possible that each NP has a different influence on the activity of such regulatory cascades. 


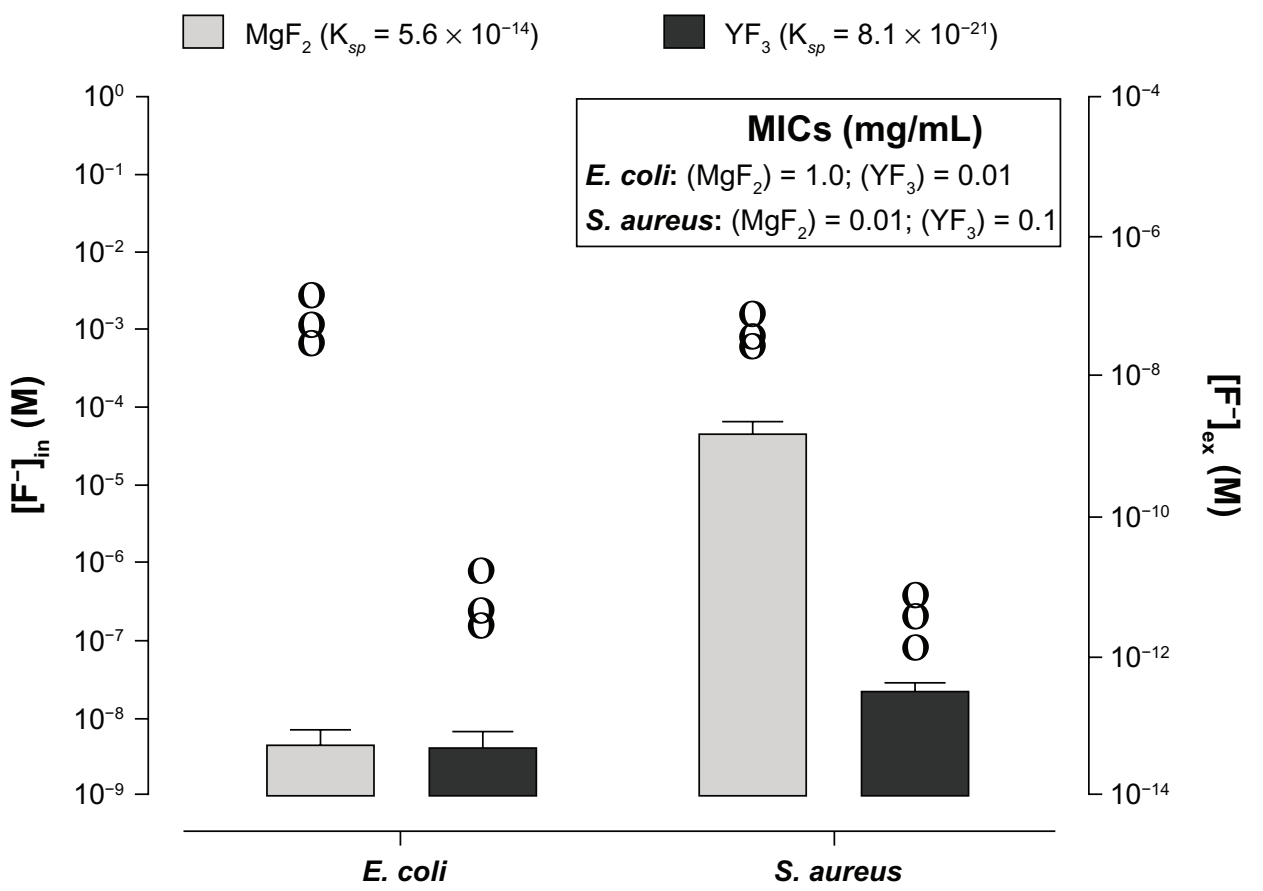

Figure 5 Influence of solubility of $\mathrm{YF}_{3}$ and $\mathrm{MgF}_{2} \mathrm{NPs}$ on the $\mathrm{F}^{-}$intracellular and extracellular concentrations.

Notes: Fluorine intracellular ( $\left[\mathrm{F}^{-}\right]_{\text {in }}$, columns-left y axis) and extracellular (ie, fluorine concentration in the surrounding media, noted at $\left[\mathrm{F}^{-}\right]_{\text {ex }}$ and represented by circles-right

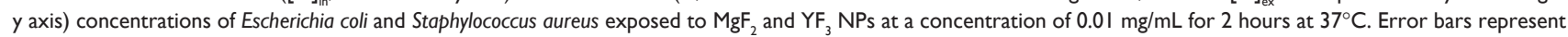
the standard deviation of three independent experiments conducted in triplicate. Each circle represents the mean of one experiment conducted in triplicate. (Insert) The MICs of E. coli and S. aureus exposed, respectively, to $\mathrm{MgF}_{2}$ and $\mathrm{YF}_{3} \mathrm{NPs}$ (taken from Figures 4 and S2).

Abbreviations: $\left[\mathrm{F}^{-}\right]_{\mathrm{ex}}$, fluorine extracellular concentration; $\left[\mathrm{F}^{-}\right]_{\mathrm{in}}$, fluorine intracellular concentration; $\mathrm{MgF}$, magnesium fluoride; $\mathrm{MICs}$, minimal inhibitory concentrations; NPs, nanoparticles; $\mathrm{YF}_{3}$, yttrium fluoride.

To test the antibiofilm activity of the $\mathrm{YF}_{3} \mathrm{NPs}$, we utilized a static biofilm assay using the same $\mathrm{YF}_{3} \mathrm{NP}$ concentrations as used in our growth curve experiments. Escherichia coli biofilm formation decreased in a dose-dependent manner and resulted in an approximately 95\% reduction in biofilm biomass at a $\mathrm{YF}_{3}$ concentration of $0.001 \mathrm{mg} / \mathrm{mL}$ (Figure 6A). A complete inhibition of $E$. coli biofilm formation was observed at a concentration of $0.01 \mathrm{mg} / \mathrm{mL}$ (Figure 6A). Staphylococcus aureus biofilm formation was completely inhibited at a $\mathrm{YF}_{3} \mathrm{NP}$ concentration of $0.1 \mathrm{mg} /$ $\mathrm{mL}$ (Figure 6B). These values correlate with the MIC concentrations; thus most likely the inhibition of biofilm formation by the suspended NPs is mediated by growth inhibition. To exclude the possibility that dissolved yttrium or fluorine ions released to the medium were responsible for the observed antibacterial activity, we conducted several control experiments. By dissolving separately two yttrium acetate and sodium fluoride precursor salts in TSB or TSBGlu, we demonstrated that $\mathrm{Y}^{+3}$ (aq) or $\mathrm{F}^{-}{ }_{\text {(aq) }}$ at a concentration of more than $10^{3}$ of the solubility of $\mathrm{YF}_{3}$ in water $\left(\mathrm{K}_{\mathrm{sp}}\right.$ with a $10^{-21}$ range $)^{38}$ did not cause similar growth or biofilm inhibitory effects on the two bacteria tested (Figure S1). Taken together, these results strongly suggest that the nanometric form of $\mathrm{YF}_{3}$ NPs plays an important factor in the observed antimicrobial activity (Figure S1).

\section{The effect of $\mathrm{YF}_{3}$ NP size on antimicrobial activity}

A major advantage of the sonochemical-based synthesis procedure is the ability to control the NP size. ${ }^{10,30}$ This is achieved by varying the concentrations of both $\left[\mathrm{Y}(\mathrm{Ac})_{3} \cdot\left(\mathrm{H}_{2} \mathrm{O}\right)_{4}\right]$ and HF components, while still maintaining their relative molar ratio at 1:3 during the ultrasonic process. Using this strategy we were able to synthesize three groups of $\mathrm{YF}_{3} \mathrm{NPs}$ that varied in length. The size range was from $360 \mathrm{~nm}$ (marked as $\left.\mathrm{YF}_{3}-1\right)$ to $150 \mathrm{~nm}$ (marked as $\mathrm{YF}_{3}-2$ ) and further to $50 \mathrm{~nm}$ (marked as $\mathrm{YF}_{3}-3$ ), as determined by the application of the Debye-Scherrer formula (Table 1). Dynamic light scattering measurements of the same products in EtOH afforded similar hydrodynamic diameters of $365 \pm 30 \mathrm{~nm}\left(\mathrm{YF}_{3}-1\right), 156 \pm 26 \mathrm{~nm}\left(\mathrm{YF}_{3}-2\right)$ and $51 \pm 10 \mathrm{~nm}$ $\left(\mathrm{YF}_{3}-3\right)($ Table 1). As expected, the surface area obtained by the BET method substantiated the size dependence of the samples. The surface area increased with decreasing NP size from approximately $20\left(\mathrm{YF}_{3}-1\right)$ to $145\left(\mathrm{YF}_{3}-3\right) \mathrm{m}^{2} / \mathrm{g}$ (Table 1). 

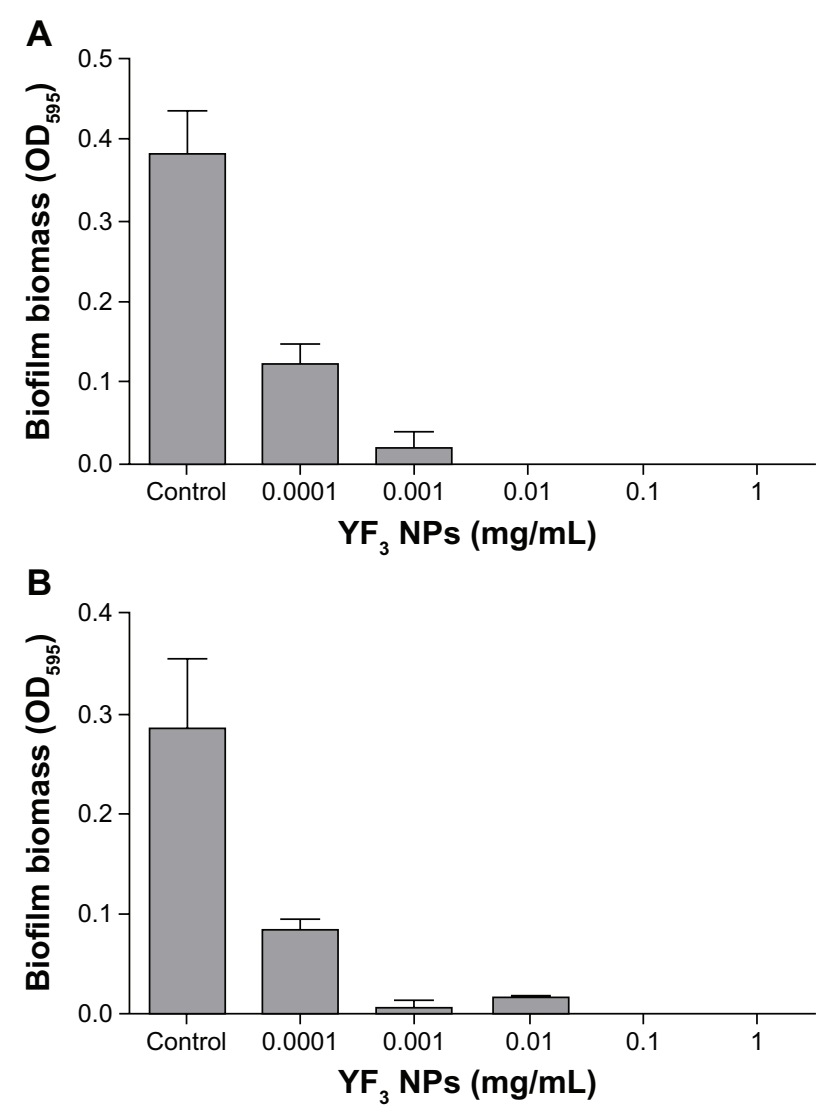

Figure 6 Antibiofilm properties of $\mathrm{YF}_{3}$ NPs.

Notes: Biofilm formation quantified after overnight incubation for (A) Escherichia coli and (B) Staphylococcus aureus exposed to variable concentrations $(0.0001$ to I mg/mL) of $\mathrm{YF}_{3} \mathrm{NP}$ solutions for 24 hours at $37^{\circ} \mathrm{C}$.

Notes: Untreated bacteria served as a control. Error bars represent the standard deviation of three independent experiments. The results were found to be statistically significant $(P<0.05)$ between control versus NP-treated cells in all treatments. Abbreviations: NP, nanoparticle; $\mathrm{OD}_{595}$, optical density at $595 \mathrm{~nm} ; \mathrm{YF}_{3}$, yttrium fluoride.

Next, we examined how changes in NP size and surface area affected antimicrobial activity. The results presented in Figure 7 clearly show a reverse correlation between NP size and antimicrobial activity for both $E$. coli and $S$. aureus (tested concentration was $0.001 \mathrm{mg} / \mathrm{mL}$ ), ie, the antimicrobial activity increased as NP size decreased. This phenomenon is not unique to the $\mathrm{YF}_{3} \mathrm{NPs}$ and has been demonstrated with other NPs, such as $\mathrm{ZnO},{ }^{10,39} \mathrm{Ag},{ }^{40,41} \mathrm{MgO},{ }^{12}$ and $\mathrm{MgF}_{2} \cdot{ }^{30}$ The change in antibacterial properties of $\mathrm{YF}_{3} \mathrm{NPs}$ are most likely

Table I Characterization of $\mathrm{YF}_{3}$ particles of different size

\begin{tabular}{llll}
\hline Sample & Debye-Scherrer $(\mathbf{n m})$ & DLS $(\mathbf{n m})$ & BET $\left(\mathbf{m}^{2} / \mathbf{g}\right)$ \\
\hline $\mathrm{YF}_{3}-\mathrm{I}$ & 358 & $365 \pm 30$ & $20.2 \mathrm{I}$ \\
$\mathrm{YF}_{3}-2$ & 150 & $156 \pm 26$ & $97.0 \mathrm{I}$ \\
$\mathrm{YF}_{3}-3$ & 49 & $5 \mathrm{I} \pm 10$ & 145.32 \\
\hline
\end{tabular}

Note: Average particle sizes (Debye-Scherrer formula), DLS, and BET multipoint surface area measurements of $\mathrm{YF}_{3} \mathrm{NP}$ samples.

Abbreviations: $\mathrm{BET}$, Brunauer-Emmett-Teller; DLS, dynamic light scattering; $\mathrm{YF}_{3}$ yttrium fluoride. due to increased surface area to volume ratio as we reduce the size of the NP. A particle with a high surface area has a greater number of reaction sites than a particle with a lower surface area and thus results in higher chemical reactivity. Moreover, a large surface reactive area of the smaller NPs enhances their interaction with the cells and may even improve the internalization of NPs in the bacteria. ${ }^{42,43}$

\section{Antibiofilm properties of $\mathrm{YF}_{3} \mathrm{NP}$-coated catheters}

The sonochemical method has been found to be an efficient method for coating NPs on a variety of substrates. ${ }^{44-47} \mathrm{In}$ sonochemistry the chemical reactions occur at $20 \mathrm{kHz}$ as a result of collapse of the acoustic bubble (Figure 1). ${ }^{48,49}$ This collapse creates very high temperatures and high pressures, conditions leading to the rupture of chemical bonds (Figure 1). ${ }^{48,49}$ According to the interpretation suggested for the sonochemical coating process, microjets directed at a solid surface and moving at very high speed $(>200 \mathrm{~m} / \mathrm{second})$ are formed after the collapse of the acoustic bubble. These microjets throw the newly formed NPs at the solid substrate at such a high speed that the NPs are able to penetrate and coat the surface (Figure 1) ${ }^{49}$ This mode of coating is a onestep process since subsequent to the formation of NPs, the coating of the planar substrate takes place. As described in the experimental procedure, catheters were coated by adding segments directly into the chemical reaction medium, using the same reaction parameters described for the synthesis of the $\mathrm{YF}_{3}$ NPs (see Materials and methods).

Our initial characterization measurements were aimed at determining the shape and size of the $\mathrm{YF}_{3}$ NPs formed in the sonochemical reaction. The $\mathrm{YF}_{3} \mathrm{NP}$-coated catheters were examined using SEM (Figure 8). The catheter surfaces were completely covered by $\mathrm{YF}_{3}$ NPs having an average size of approximately $340 \mathrm{~nm}$ (Figure 8). The size and morphology were similar to the data measured by HR-TEM (Figure 3B) and XRD (Figure 3A) for the NPs formed under similar reaction conditions but without the catheters.

Quantification of the $\mathrm{YF}_{3} \mathrm{NPs}$ deposited during the synthesis was conducted, and the amount of NPs deposited was $0.06 \pm 0.015 \mathrm{mg} / \mathrm{cm}^{2}$. We also evaluated the homogeneity of the coating deposition by elemental mapping analysis of yttrium and fluorine using energy-dispersive spectroscopy (Figure 8). $\mathrm{YF}_{3} \mathrm{NP}$-coated catheters present a large and homogeneous distribution of the signals emitted from yttrium and fluorine detection. We also scanned the uncoated catheters and could not find yttrium or fluorine. 

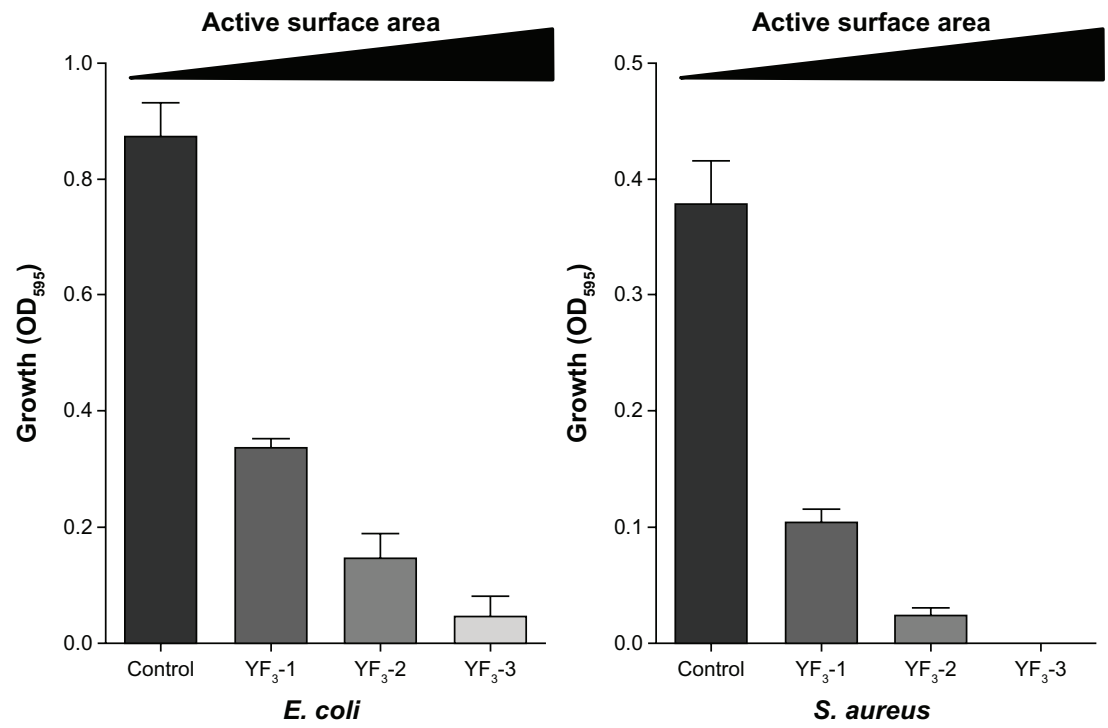

Figure 7 Impact of size of $\mathrm{YF}_{3}$ NPs on antimicrobial activity.

Notes: Growth yields of Escherichia coli and Staphylococcus aureus grown in the presence of $\mathrm{YF}_{3} \mathrm{NP}(0.00 \mathrm{I} \mathrm{mg} / \mathrm{mL})$ suspension at different sizes (samples I-3) for 24 hours at $37^{\circ} \mathrm{C}$. Untreated bacteria served as a control. Error bars represent the standard deviation of three independent experiments. The results were found to be statistically significant $(P<0.05)$ between control versus NP-treated cells in all treatments.

Abbreviations: NP, nanoparticle; $\mathrm{OD}_{595}$, optical density at $595 \mathrm{~nm} ; \mathrm{YF}_{3}$, yttrium fluoride.

The $\mathrm{YF}_{3}$ NP-coated catheters were then tested for their ability to restrict the bacterial colonization of $E$. coli and $S$. aureus. Figure 9 presents the corresponding viable counts that depict biofilm development following 24 hours of bacterial exposure. The untreated surfaces supported massive biofilm formation

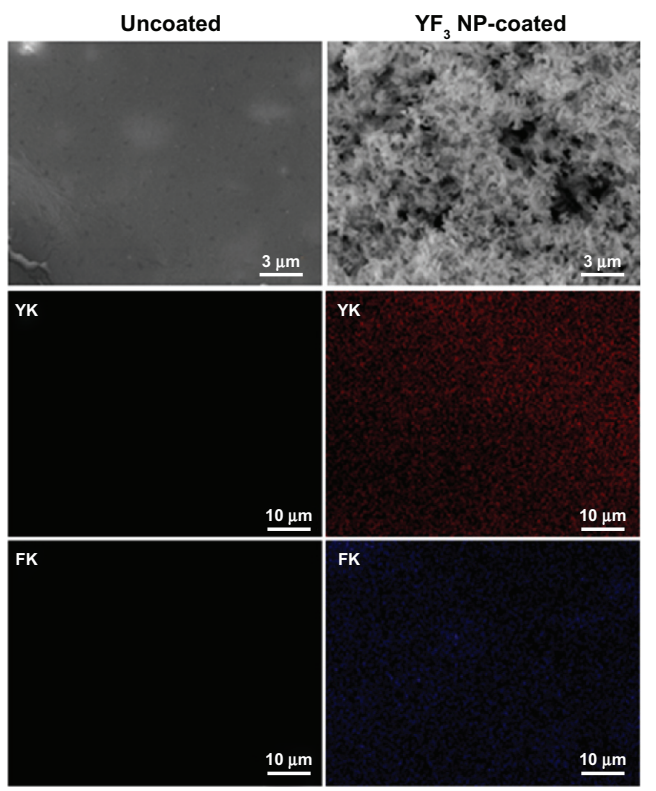

Figure 8 Imaging and characterization of sonochemical $\mathrm{YF}_{3}$ NP catheter coating. Notes: Catheters were coated using a sonochemical procedure described in the experimental section. SEM images of the internal walls of uncoated and $\mathrm{YF}_{3} \mathrm{NP}$ coated catheters are presented. The distribution of the $\mathrm{YF}_{3} \mathrm{NP}$ coating on the catheter's surface characterized by X-ray dot mapping of yttrium (red) and fluor (purple) atoms signals detected on the internal catheter wall.

Abbreviations: K, K line energy; NP, nanoparticle; SEM, scanning electron microscope; $\mathrm{YF}_{3}$, yttrium fluoride. $\left(6.7 \times 10^{7}\right.$ and $3.8 \times 10^{7} \mathrm{CFU} / \mathrm{cm}^{2}$ for E. coli and S. aureus, respectively) in comparison with $\mathrm{YF}_{3} \mathrm{NP}$-coated catheters. The results suggest that the $\mathrm{YF}_{3} \mathrm{NP}$-coated catheters effectively inhibited bacterial adhesion and biofilm formation. Similar to the results obtained with planktonic cultures, S. aureus seems to be less sensitive to the $\mathrm{YF}_{3} \mathrm{NP}$-coated catheters in comparison with E. coli. No E. coli cells were observed on the NP-coated catheters, whereas a small number of $S$. aureus cells were detected

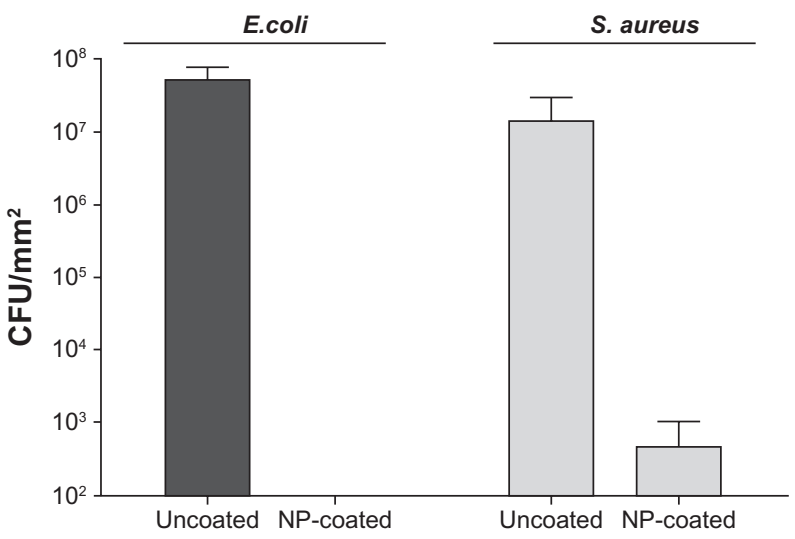

Figure 9 Antibiofilm properties of the catheter coated with $\mathrm{YF}_{3}$ NPs against formation of biofilms by Escherichia coli and Staphylococcus aureus.

Notes: Viable counts of the biofilm cells of $E$. coli and S. aureus, grown in TSB and TSB-Glu, on the internal wall of a $\mathrm{YF}_{3}$ NP-coated catheter incubated for 24 hours at $37^{\circ} \mathrm{C}$. Uncoated catheters served as the negative control. Bars represent the standard deviation of three independent experiments conducted in triplicate. The results were found to be statistically significant $(P<0.05)$ between uncoated versus NP-coated catheters in all treatments.

Abbreviations: CFU, colony forming units; NP, nanoparticle; TSB, tryptic soy broth; TSB-Glu, tryptic soy broth supplemented with $0.2 \%$ glucose; $\mathrm{YF}_{3}$, yttrium fluoride. 
on the surface. The exact mechanism by which the $\mathrm{YF}_{3} \mathrm{NPs}$ mediated these processes is still unclear and requires additional study; however, similar results were seen with $\mathrm{MgF}_{2} \mathrm{NPs}^{30,33}$

\section{Conclusion}

This study characterized the antibacterial and antibiofilm activities of crystalline $\mathrm{YF}_{3}$ NPs obtained by sonochemical synthesis against two common bacterial pathogens. Antimicrobial activity was observed at millimolar concentrations and was strongly dependent on particle size for both bacteria, with smaller sized NPs having more efficient antibacterial activity than larger NPs. We further utilized the sonochemical irradiation procedure to effectively coat catheter surfaces with $\mathrm{YF}_{3}$ NPs. Our results revealed that this procedure provides a stable and homogeneous coating. The coated catheters effectively restricted biofilm formation by the studied bacteria. The results of this study emphasize the potential use of $\mathrm{YF}_{3} \mathrm{NPs}$ as a new approach for the design of sterile surface coatings that may be useful for various medical applications.

\section{Acknowledgments}

This research was carried out as part of the activities of the KAMIN project financed by the Israeli Ministry of Industry, Trade and Labor to EB. This research was carried out as part of the activities of the NOVO Consortium. NOVO, is an investigatory project of the Seventh European Commission Program, HEALTH.2011.2.3.1-5 (Contract No 278402) to AG. This research is part of the requirements for a $\mathrm{PhD}$ thesis for JL at Bar-Ilan University. We confirm that the manuscript has been read and approved by all named authors and that there are no other persons who satisfied the criteria for authorship. We further confirm that the order of authors listed in the manuscript has been approved by all of us.

\section{Disclosure}

We confirm that there are no known conflicts of interest associated with this publication and there has been no significant financial support for this work that could have influenced its outcome.

\section{References}

1. Jain K, Kesharwani P, Gupta U, Jain NK. A review of glycosylated carriers for drug delivery. Biomaterials. 2012;33(16):4166-4186.

2. Tang FQ, Li LL, Chen D. Mesoporous silica nanoparticles: synthesis, biocompatibility and drug delivery. Adv Mater. 2012;24(12): 1504-1534.

3. Grangvist CG. Preparation of thin films and nanostructured coatings for clean tech applications: a primer. Sol Energ Mat Sol C. 2012;99(SI): 166-175.

4. Shilo M, Reuveni T, Motiei M, Popovtzer R. Nanoparticles as computed tomography contrast agents: current status and future perspectives. Nanomedicine-UK. 2012;7(2):257-269.
5. Leung KCF, Xuan SH, Zhu XM, Wang DW, Chak CP, Lee SF, et al. Gold and iron nanocomposite materials. Chem Soc Rev. 2012;41(5): 1911-1928.

6. Spagnolo F. Antibiotic resistance: understanding and responding to an emerging crisis. Q Rev Biol. 2011;86(4):366-366.

7. Woodford N, Turton JF, Livermore DM. Multiresistant Gram-negative bacteria: the role of high-risk clones in the dissemination of antibiotic resistance. FEMS Microbiol Rev. 2011;35(5):736-755.

8. Cui Y, Zhao YY, Tian Y, Zhang W, Lu XY, Jiang XY. The molecular mechanism of action of bactericidal gold nanoparticles on Escherichia coli. Biomaterials. 2012;33(7):2327-2333.

9. Ortega-Calvo JJ, Molina RM, Jimenez-Sanchez C, Dobson PJ, Thompson IP. Bacterial tactic response to silver nanoparticles. Environ Microbiol Reports. 2011;3(5):526-534.

10. Applerot G, Lipovsky A, Dror R, Perkas N, Nitzan Y, Lubart R, et al. Enhanced antibacterial activity of nanocrystalline $\mathrm{ZnO}$ due to increased ROS-mediated cell injury. Adv Funct Mater. 2009;19(6):842-852.

11. Jin T, He YP. Antibacterial activities of magnesium oxide (MgO) nanoparticles against foodborne pathogens. J Nanopart Res. 2011;13(12): 6877-6885.

12. Makhluf S, Dror, Nitzan Y, Abramovich Y, Jelinek R, Gedanken A. Microwave-assisted synthesis of nanocrystalline $\mathrm{MgO}$ and its use as a bacteriocide. Adv Funct Mater. 2005;15(10):1708-1715.

13. Ren GG, Hu DW, Cheng EWC, Vargas-Reus MA, Reip P, Allaker RP. Characterization of copper oxide nanoparticles for antimicrobial applications. Int J Antimicrob Ag. 2009;33(6):587-590.

14. Pandey P, Merwyn S, Agarwal GS, Tripathi BK, Pant SC. Electrochemical synthesis of multi-armed $\mathrm{CuO}$ nanoparticles and their remarkable bactericidal potential against waterborne bacteria. J Nanopart Res. 2012;14(1):1-13.

15. Dutta RK, Nenavathu BP, Gangishetty MK, Reddy AVR. Studies on antibacterial activity of $\mathrm{ZnO}$ nanoparticles by ROS induced lipid peroxidation. Colloid Surface B. 2010;94(3):143-150.

16. Lipovsky A, Levitski L, Tzitrinovich ZT, Gedanken A, Lubart R. The different behavior of rutile and anatase nanoparticles in forming oxy radicals upon illumination with visible light: an EPR study. Photochem Photobiol. 2012;88(1):14-20.

17. Lipovsky A, Nitzan Y, Gedanken A, Lubart R. Visible light-induced killing of bacteria as a function of wavelength: implication for wound healing. Laser Surg Med. 2010;42(6):467-472.

18. Costerton JW, Stewart PS, Greenberg EP. Bacterial biofilms: a common cause of persistent infections. Science. 1999;284(5418):1318-1322.

19. Hoiby N, Ciofu O, Johansen HK, Song ZJ, Moser C, Jensen PO, et al. The clinical impact of bacterial biofilms. Int J Oral Sci. 2011;2(2):55-65.

20. Hoiby N, Bjarnsholt T, Givskov M, Molin S, Ciofu O. Antibiotic resistance of bacterial biofilms. Int J Antimicrob Ag. 2010;35(4): $322-332$.

21. Darouiche RO. Current concepts: treatment of infections associated with surgical implants. New Engl J Med. 2004;350(14):1422-1429.

22. Applerot G, Lellouche J, Perkas N, Gedanken A, Banin E. ZnO nanoparticle-coated surfaces inhibit bacterial biofilm formation and increase antibiotic susceptibility. RSC Advances. 2012;2(6):2314-2321.

23. Roe D, Karandikar B, Bonn-Savage N, Gibbins B, Roullet JB. Antimicrobial surface functionalization of plastic catheters by silver nanoparticles. J Antimicrob Chemoth. 2008;61(4):869-876.

24. Shi ZL, Neoh KG, Kang ET, Wang W. Antibacterial and mechanical properties of bone cement impregnated with chitosan nanoparticles. Biomaterials. 2006;27(11):2440-2449.

25. Flemming RG, Capelli CC, Cooper SL, Proctor RA. Bacterial colonization of functionalized polyurethanes. Biomaterials. 2000;21(3): 273-281.

26. Beyth N, Houri-Haddad Y, Baraness-Hadar L, Yudovin-Farber I, Domb AJ, Weiss EI. Surface antimicrobial activity and biocompatibility of incorporated polyethylenimine nanoparticles. Biomaterials. 2008; 29(31):4157-4163.

27. Marquis RE. Antimicrobial actions of fluoride for oral bacteria. Can J Microbiol. 1995;41(11):955-964. 
28. Marquis RE, Clock SA, Mota-Meira M. Fluoride and organic weak acids as modulators of microbial physiology. FEMS Microbiol Rev. 2003;26(5):493-510.

29. Lellouche J, Kahana E, Elias S, Gedanken A, Banin E. Antibiofilm activity of nanosized magnesium fluoride. Biomaterials. 2009;5(7): 5969-5978.

30. Lellouche J, Friedman A, Lellouche JP, Gedanken A, Banin E. Improved antibacterial and antibiofilm activity of magnesium fluoride nanoparticles obtained by water-based ultrasound chemistry. NanomedNanotechnol. 2011;8(5):702-711.

31. International Centre for Diffraction Data (ICDD) [homepage on the Internet], available from: http://www.icdd.com

32. International Centre for Diffraction Data (ICDD) [homepage on the Internet], available from: http://www.icdd.com

33. Lellouche J, Friedman A, Lahmi R, Gedanken A, Banin E. Antibiofilm surface functionalization of catheters by magnesium fluoride nanoparticles. Int J Nanomed. 2012;7(2):1175-1188.

34. Souza Antunes AL, Trentin DS, Bonfanti JW, Ferreira Pinto CC, Rodrigues Perez AJ, Macedo AJ, et al. Application of a feasible method for determination of biofilm antimicrobial susceptibility in staphylococci. APMIS. 2010;118(11):168-192.

35. Dewanti R, Wong ACL. Influence of culture conditions on biofilm formation by Escherichia coli O157:H7. Int J Food Microbiol. 1995; 26(2):147-164.

36. Woong KS, Youn-Joo A. Effect of $\mathrm{ZnO}$ and $\mathrm{TiO} 2$ nanoparticles preilluminated with UVA and UVB light on Escherichia coli and Bacillus subtilis. Appl Microbiol Biot. 2012;95(1):243-253.

37. Baker JL, Sudarsan N, Weinberg Z, Roth A, Stockbridge RB, Breaker RR. Widespread genetic switches and toxicity resistance proteins for fluoride. Science. 2012;335(6065):233-235.

38. Haynes WM. Handbook of Chemistry and Physics. 92 ed. CRC press; Boca Raton, FL. 2007.

39. Raghupathi KR, Koodali RT, Manna AC. Size-dependent bacterial growth inhibition and mechanism of antibacterial activity of zinc oxide nanoparticles. Langmuir. 2011;27(7):4020-4028.
40. Carlson C, Hussain SM, Schrand AM, Braydich-Stolle LK, Hess KL, Jones RL, et al. Unique cellular interaction of silver nanoparticles: size-dependent generation of reactive oxygen species. J Phys Chem B. 2008;112(43):13608-13619.

41. PanácčekA, Kvítek L, Prucek R, Kolář M, Vecčeřová R, Pizúrová N, et al. Silver colloid nanoparticles: synthesis, characterization, and their antibacterial activity. J Phys Chem B. 2006;110(33):16248-16253.

42. Chithrani BD, Chan WCW. Elucidating the mechanism of cellular uptake and removal of protein-coated gold nanoparticles of different sizes and shapes. Nano Lett. 2007;7(6):1542-1550.

43. Chithrani BD, Ghazani AA, Chan WCW. Determining the size and shape dependence of gold nanoparticle uptake into mammalian cells. Nano Lett. 6(4):662-668.

44. Applerot G, Abu-Mukh R, Irzh A, Charmet J, Keppner H, Laux E, et al. Decorative parylene-coated glass with $\mathrm{ZnO}$ nanoparticles for antibacterial applications: a comparative study of sonochemical, microwave, and microwave-plasma coating routes. ACS Apll Mater Interfaces. 2010; 2(4):1052-1059

45. Soloviev M, Gedanken A. Coating a stainless steel plate with silver nanoparticles by the sonochemical method. Ultrason Sonochem. 2010; 18(1):356-362.

46. Gottesman R, Shukla S, Perkas N, Solovyov LA, Nitzan Y, Gedanken A. Sonochemical coating of paper by microbiocidal silver nanoparticles. Langmuir. 2011;27(16):720-726.

47. Perelshtein I, Applerot G, Perkas N, Grinbalt J, Hulla H, WehrschuetzSigl E, et al. Ultrasound radiation as a "throwing stones" technique for the production of antibacterial nanocomposite textiles. ACS Apll Mater Interfaces. 2010;2(7):1999-2004.

48. Flint EB, Suslick KS. The temperature of cavitation. Science. 1991;253(5026):1397-1399.

49. Suslick KS, Price GJ. Applications of ultrasound to materials chemistry. Annu Rev Mater Sci. 1999;29(4):295-326. 


\section{Supplementary figures}
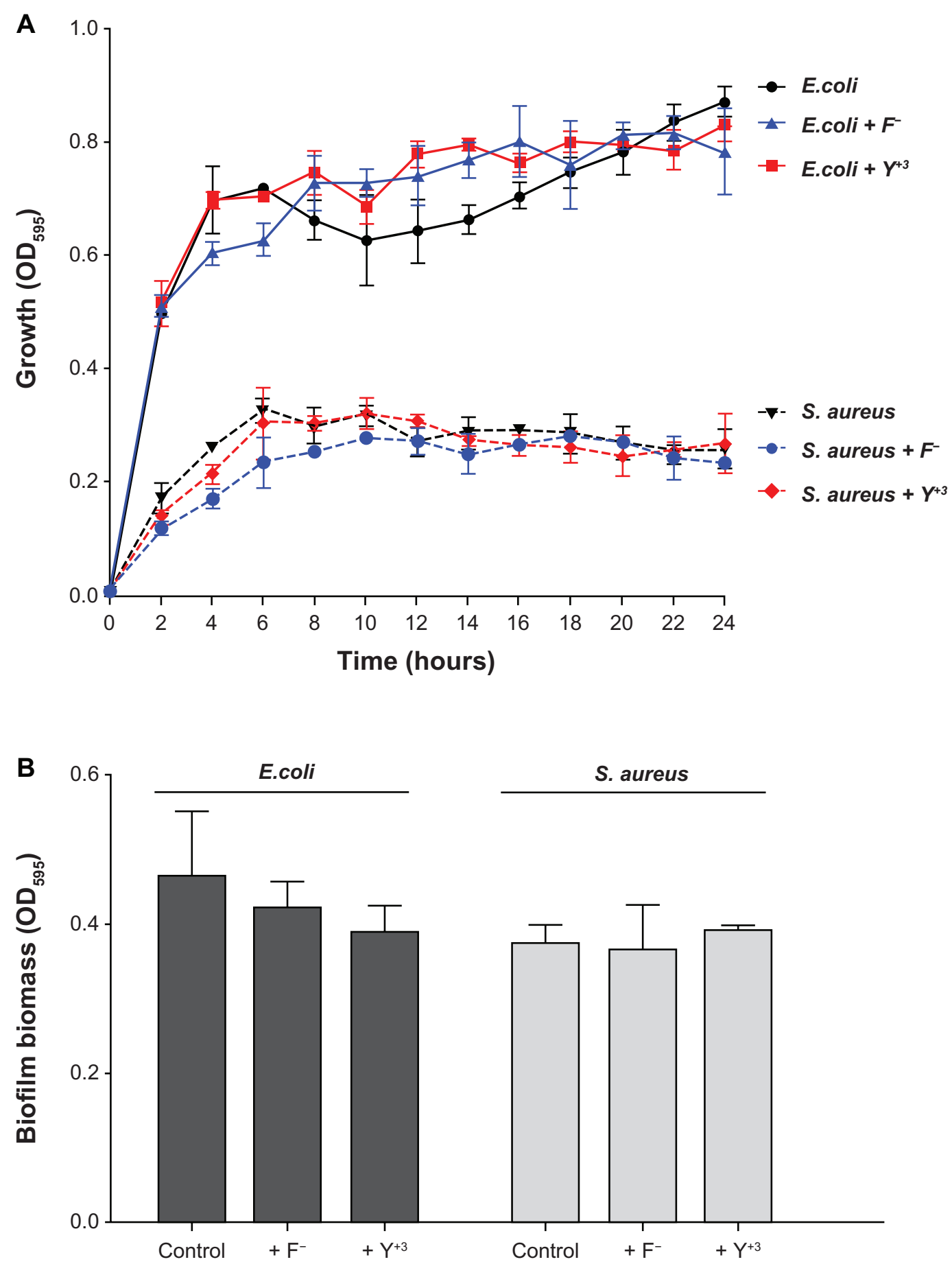

Figure SI Growth curves $(\mathbf{A})$ and biofilm formation $(\mathbf{B})$ of Escherichia coli and Staphylococcus aureus exposed to fluorine $(100 \mu \mathrm{g} / \mathrm{mL})$ and yttrium ions (I00 $\mu \mathrm{g} / \mathrm{mL})$ for 24 hours at $37^{\circ} \mathrm{C}$.

Notes: Untreated bacteria served as a control. Error bars represent the standard deviation of three independent experiments conducted in triplicate. Abbreviation: $O D_{595}$, optical density at $595 \mathrm{~nm}$. 

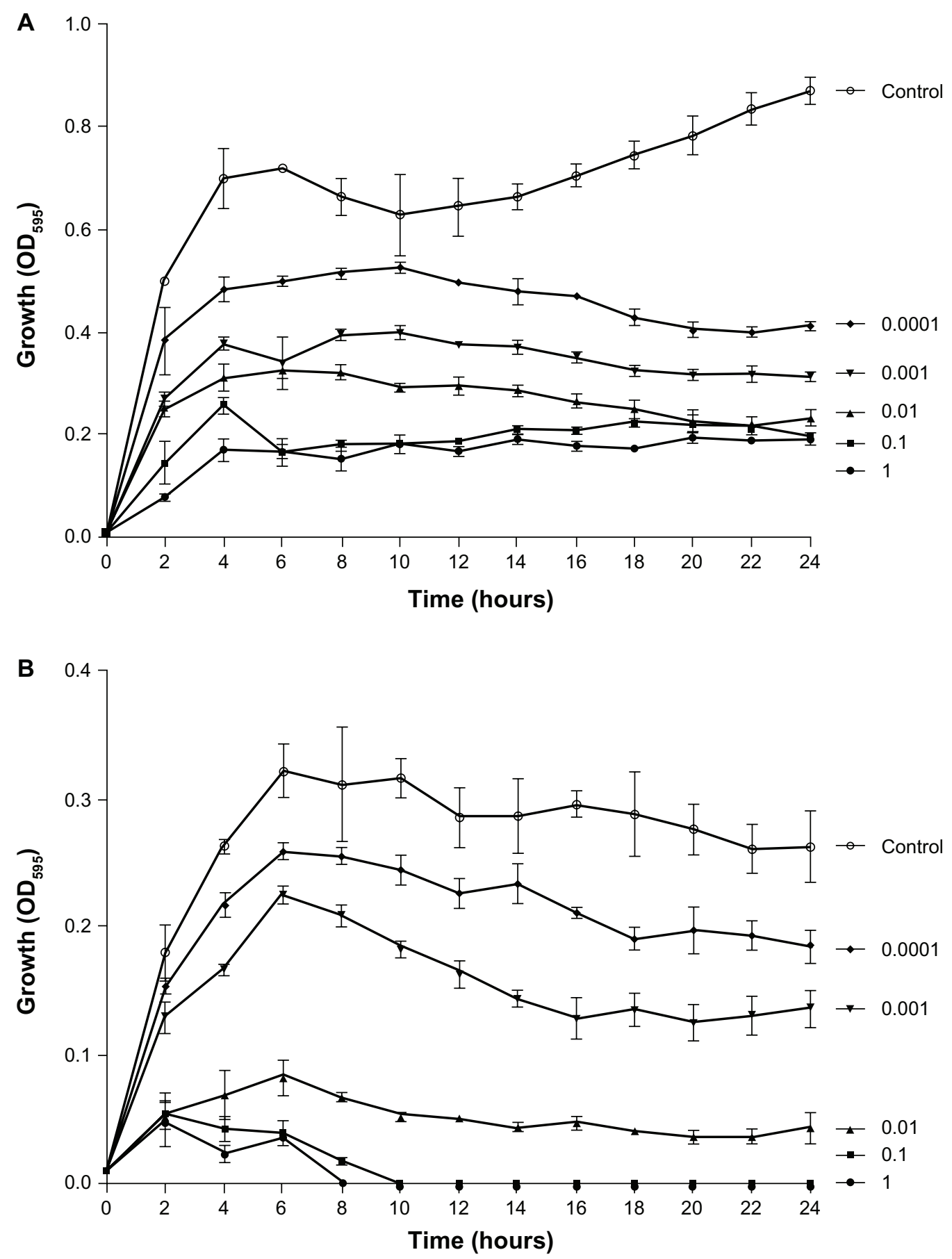

Figure S2 Antimicrobial effect of $\mathrm{MgF}_{2} \mathrm{NPs}$. Growth curves of $(\mathbf{A})$ Escherichia coli and (B) Staphylococcus aureus exposed to variable concentrations (0.000I to I mg/mL) of $\mathrm{MgF}_{2} \mathrm{NP}$ solutions for 24 hours at $37^{\circ} \mathrm{C}$.

Notes: Untreated bacteria served as a control. Error bars represent the standard deviation of three independent experiments conducted in triplicate. Abbreviations: $\mathrm{MgF}_{2}$, magnesium fluoride; $\mathrm{OD}_{595}$, optical density at $595 \mathrm{~nm}$; NPs, nanoparticles.

\section{Publish your work in this journal}

The International Journal of Nanomedicine is an international, peerreviewed journal focusing on the application of nanotechnology in diagnostics, therapeutics, and drug delivery systems throughout the biomedical field. This journal is indexed on PubMed Central, MedLine, CAS, SciSearch $\AA$, Current Contents $\AA /$ Clinical Medicine,
Journal Citation Reports/Science Edition, EMBase, Scopus and the Elsevier Bibliographic databases. The manuscript management system is completely online and includes a very quick and fair peer-review system, which is all easy to use. Visit http://www.dovepress.com/ testimonials.php to read real quotes from published authors. 